Hibbert, H., Tipson, R. S. \& Brauns, F. (193I). Canad. F. Res. 4, 22 I.

Hirst, E. L. (1942). F. chem. Soc. p. 70.

Hirst, E. L. (1949). F. chem. Soc. p. 522.

Hirst, E. L., Isherwood, F. A., Jermyn, M. A. \& Jones, J. K. N. (I949). J. chem. Soc. p. S 182.

Hirst, E. L., McGilvray, D. I. \& Percival, E. G. V. (1950). F. chem. Soc. p. 1297.

Laidlaw, R. A. \& Reid, S. G. (1951). F. chem. Soc. p. 1830.

Laidlaw, R. A. \& Reid, S. G. (1952). F. Sci. Food Agric. 3, 19.

Nanji, D. R. \& Norman, A. G. (1928). Biochem. F. 22, 599.

Palmer, A. (r $95 \mathrm{I})$. Biochem. F. 48, 389 .

Percival, E. G. V. \& Chanda, S. K. (1950). Nature, Lond., 166, 787.

Percival, E. G. V. \& Ross, A. G. (1949). F. chem. Soc. p. 304 r.

Percival, E. G. V. \& Telfer, R. C. S. (195I). Unpublished.

Schlubach, H. H. \& Bandmann, C. (1939). Liebigs Ann. 540, 285.

Schlubach, H. H. \& Huchting, I. (1949). Liebigs Ann. 561, I 73 .

Schlubach, H. H. \& Sinh, O. K. (1940). Liebigs Ann. 544, 101.

\title{
The Utilization of the Minerals, Vitamins and other Constituents of Grass
}

\section{By K. L. Blaxter, Hannah Dairy Research Institute, Kirkhill, Ayr}

Animals that spend their lives on pastures must receive from the herbage all the essential nutrients they require for growth and reproduction. The utilization of the proteins and carbohydrates of grass has already been discussed (Synge, 1952; Percival, 1952), and it now remains to examine the utilization of minerals and vitamins. At the same time, however, the presence of toxic factors in grass and the nutritional hazards which beset the grazing animal must be considered.

Before the adequacy of grasses and clovers in terms of mineral and vitamin content can be assessed, some approximate idea of the requirements of farm livestock for these entities must be obtained. In this respect recommended dietary allowances (Guilbert \& Loosli, I949, I95 I) may not provide an adequate assessment, since such requirements of minerals and vitamins tend to be overestimates and include large margins of safety. Minimum requirements (Mitchell \& McClure, 1937), expressed as percentages of the dry matter of the ration, should give an indication of the lower limits which are permissible in the composition of the diet. A pasture or grass containing less than this quantity can then be judged to be deficient. This does not mean that deficiency symptoms in their classical sense will arise on such pasture. Animals have considerable abilities to adapt themselves to suboptimal nutrition. These adaptive processes, however, inevitably involve slight declines in growth rate, milk yield, egg production and reproductive performance.

High rates of growth and production not only entail higher requirements per head of stock, but higher concentrations of most nutrients in the dietary dry matter. Thus to produce one egg a day the hen requires $3 \%$ calcium in her diet whereas to produce none she requires only one-tenth this amount. Similarly, the mature cow requires as an absolute minimum $0.17 \%$ phosphorus in her diet if she produces no milk and is not pregnant. She requires half as much again to produce 3 gal. milk a day, and almost double this quantity when lactating during the terminal phases of pregnancy.

Table i summarizes data on minimum requirements of $\mathrm{Ca}$ and $\mathrm{P}$ for farm livestock. Methods and data used for this purpose are given in the footnote to Tables I and 2. 
Table 1. Minimal calcium and phosphorus requirements of growing and producing animals expressed as a percentage of dry matter ingested ${ }^{*} \dagger$

\begin{tabular}{lcc} 
& \multicolumn{2}{c}{ Growing } \\
Species & $\mathrm{Ca}$ & $\mathrm{P}$ \\
Horse & 0.3 & 0.25 \\
Sheep & $0.15-0.2$ & $0.15-0.2$ \\
Cow & $0.2-0.3$ & $0.2-0.3$ \\
Pig & 0.3 & 0.3 \\
Hen & 0.8 & 0.4
\end{tabular}

Producing (gestation, lactation, egg production)

$\begin{array}{cc}\mathrm{Ca} & \mathrm{P} \\ ? & ? \\ 0.2 & 0.2 \\ 0.3 & 0.3 \\ 0.5 & 0.4 \\ 3.0 & 0.5\end{array}$

- Requirements depend on the rate of growth and of milk and egg production, but the values quoted do allow for high levels of production. The values for growing animals do not apply to the very young suckling when they approach $\mathrm{I} \%$ of the dry matter for $\mathrm{Ca}$ and $0.6 \%$ for $\mathrm{P}$.

$t$ The food intakes of animals of different species in terms of dietary dry matter were taken from Guilbert \& Loosli (1949, I95 I). The Ca and P requirements are essentially those calculated by Mitchell \& McClure (1937) and reviewed and amended by Mitchell (1947). They agree very well with experimental observations made with rations containing minimal quantities of $\mathrm{Ca}$ and $\mathrm{P}$. Thus, minimal $\mathrm{P}$ requirements have been assessed from feeding experiments with cattle to be more than $O^{\prime} I 3$ and less than $0.26 \%$ of the dry matter of the ration (Henderson \& Weakley, 1930; Reed \& Huffiman, 1930). In general, the lower limits of $\mathrm{Ca}$ and $\mathrm{P}$ requirements have been taken. The copper and cobalt requirements are based on the data assembled and reviewed by Russell (1944). The manganese requirement derives from studies of Lyons (1939) and of Gutowska \& Parkhurst (1942). No data on the requirement of cattle or sheep are available. Vitamin A requirements are based on a requirement of 25-30 $\mu \mathrm{g}$ $\beta$-carotene $/ \mathrm{kg}$ body-weight (Guilbert, Howell \& Hart, 1940) together with data on food intake. Vitamin D requirements were recalculated from the data of Guilbert \& Loosli (195I) and are recommended allowances rather than minimal quantities. Requirements of aneurin were based on a consideration of the data of Amold \& Elvehjem (1938) and Van Etten, Ellis \& Madsen (1940). Cowgill's studies (Cowgill \& Palmieri, 1933) have shown that the aneurin requirement is determined by food consumption rather than metabolic rate. Requirements of the remainder of the vitamins of the $\mathrm{B}$ complex have also been referred to food intake, and the values given are those computed by Mitchell (1950). Since the animal requires most minor elements and B-complex vitamins to furnish part or all of the prosthetic groups of enzymes or to activate enzymic processes involved in the metabolism of dietary energy and protein it is logical to refer requirements for these nutrients to the quantity of food ingested rather than to body size or function. This step greatly facilitates the appraisal of dietaries.

The generalization of the requirements of individual species has been made in such a way as to avoid possible malnutrition of one species. Thus, with respect to $\mathrm{Ca}$ and $\mathrm{P}$, as shown in Table $\mathrm{I}$, the horse has the highest minimal requirement of the three herbivora listed. These values for the horse have been taken as minimal requirements for herbivorous livestock, since their use as a criterion of adequacy then allows for a full utilization of a pasture or dietary regimen by all herbivorous species.

Table 2. Approximate minimal requirements of essential nutrients for herbivora and for pigs and poultry, expressed in relation to the dry matter ingested. The requirements for high levels of egg and milk production may not be adequately covered*

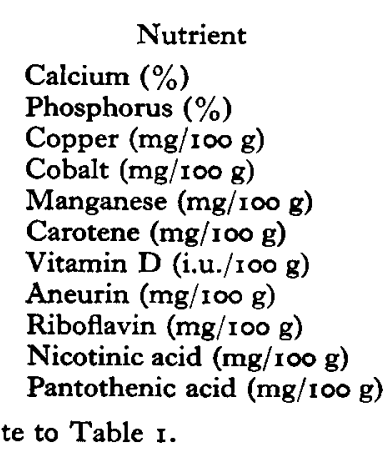

- See footnote to Table I.

\begin{tabular}{|c|c|}
\hline \multicolumn{2}{|c|}{ Species } \\
\hline Herbivora & Pigs and poultry \\
\hline $\begin{array}{l}0.3 \\
0.25\end{array}$ & $\begin{array}{l}0.8 \\
0.5\end{array}$ \\
\hline 0.3 & \\
\hline 0.01 & Not required $\dagger$ \\
\hline$?$ & 4 \\
\hline I & 0.5 \\
\hline $\begin{array}{l}45 \\
\text { Not required }\end{array}$ & $\begin{array}{l}45 \\
0 \cdot I\end{array}$ \\
\hline Not required & 0.15 \\
\hline Not required & 1.00 \\
\hline Not required & 0.5 \\
\hline
\end{tabular}

$\uparrow$ Required as a component of vitamin $B_{11}$. 
Except for the hen, Ca requirements may be placed at not less than $0.3 \%$ of the dry matter of the ration and $\mathrm{P}$ requirements at not less than $0.25 \%$. These figures are only rough approximations. They do not take into account the high requirement of the very young animal. The cow or ewe, however, will provide milk containing up to $\mathrm{I} \cdot 5 \% \mathrm{Ca}$ and $\mathrm{I} \cdot 4 \% \mathrm{P}$ in the dry matter to meet this requirement of the suckling. The requirement of the pig for very rapid growth is higher than the minimum listed, and so we can perhaps pool pigs and poultry with requirements approximately double those of herbivora.

Table 3. Limitations of grasses, clovers and pastures in meeting minimal calcium and phosphorus requirements

\begin{tabular}{|c|c|c|}
\hline & $\begin{array}{c}\mathrm{Ca} \\
\text { (percentage of } \\
\text { dry matter) }\end{array}$ & $\begin{array}{c}P \\
\text { (percentage of } \\
\text { dry matter) }\end{array}$ \\
\hline \multicolumn{3}{|l|}{ Minimal requirements: } \\
\hline Herbivora & 0.3 & 0.25 \\
\hline Pigs and poultry & 0.8 & 0.5 \\
\hline \multirow{2}{*}{\multicolumn{3}{|c|}{ Content in: }} \\
\hline Individual plant species grown on good soils: & & \\
\hline Clovers* & $1 \cdot 0-2 \cdot 0$ & $0.25-0.60$ \\
\hline Grasses & $0.3-0.4$ & $0.10-0.30$ \\
\hline 'Herbs' & Up to $3 \cdot 0$ & $0.25-0.40$ \\
\hline Moorland plants (e.g. Nardus, Molinia, Vaccinium) $\dagger$ & $0.09-0.5$ & $0.08-0.40$ \\
\hline Pastures (mixed species): & & \\
\hline Cultivated pasture $\downarrow$ & $0 \cdot 78$ & 0.34 \\
\hline County Dublin best pasture $\S$ & 0.56 & 0.52 \\
\hline Hannah Institute fertilized pasture $\|$ & 0.90 & 0.40 \\
\hline Good Scots hill pasture f & 0.39 & 0.26 \\
\hline Aphosphorosis area, South Africa I & 0.35 & 0.08 \\
\hline Aphosphorosis area, Offally $\S$ & 0.84 & 0.13 \\
\hline 'Croitich' area, Scotland $f$ & $0 \cdot 15$ & 0.13 \\
\hline 'Knochenbrüchigkeit' area, Austria"* & 0.49 & $0 \cdot 10$ \\
\hline
\end{tabular}

Bold figures indicate values lower than the estimates of minimal requirements of herbivora.

* Fagan (1931); Mitchell \& McClure (1937); Thomas \& Thompson (1948); Watson (1939); Schneider (1947).

† Thomas, Escritt \& Trinder (I945); Thomas \& Trinder (1947).

$\S$ Sheehy, O'Donovan, Day \& Curran (1948).

I Theiler, Green \& Viljoen (1915).

$\ddagger$ Orr (1929).

II Holmes (I949).

* Roloff (1866).

Similar tabulations have been made for other nutrient requirements using what scanty information is available in the literature, and generalizations regarding requirements of herbivora and of pigs and poultry have again been made; Table 2 summarizes what may be taken as lower approximate limits for the essential nutrients that grass should provide. Some entries in the table need explanation. The carotene requirement of an animal is directly in proportion to body-weight and is approximately $30 \mu \mathrm{g} / \mathrm{kg}$ body-weight (Guilbert et al. 1940), whereas food capacity tends to be proportionate to surface area. The requirements of small animals for carotene are therefore smaller per unit of food than those of large animals. Similarly, the requirements for the vitamin B complex are, broadly speaking, proportional to the non-fat calories metabolized, and the minimal requirements given are based not only on experimental results with pigs and poultry but also on trials with rats, dogs and man.

Calcium and phosphorus. With these base-lines of minimal requirement established, we can now examine pastures and individual species. Table 3 summarizes information 
on the $\mathrm{Ca}$ and $\mathrm{P}$ content of herbage from different areas. The table shows the superiority of clovers over grasses as sources of $\mathrm{Ca}$ and $\mathrm{P}$, as well as the value of certain so-called herbs. It also emphasizes the inadequacy of the poor moorland plants of highland grazings. Some pastures listed are high-quality pastures and their composition is quite adequate. Such limited figures do not, however, give the entire picture. The $\mathrm{Ca}$ and $\mathrm{P}$ content of herbage varies markedly during the growing season, $\mathrm{Ca}$ tending to accumulate and $\mathrm{P}$ to decline. Fertilizer application can increase both the $\mathrm{Ca}$ and $\mathrm{P}$ content of herbage, more on poor soils than on good ones, whereas drought, flooding and those differences in management that affect growth stages and botanical composition all influence the composition to a considerable extent. On occasions even a good pasture may show low values for both $\mathrm{P}$ and $\mathrm{Ca}$, but it is very doubtful whether these short-term changes in $\mathrm{Ca}$ and $\mathrm{P}$ supply to the animal have much effect on productivity. The remaining pastures listed are all grossly deficient ones on which recognizable maladies of livestock occur. Aphosphorosis, which occurs when the $P$ content falls below about $0.18 \%$, is recognized in almost every country of the world and many hundreds of thousands of square miles of grazing for cattle and sheep are affected. The loin disease of Texas, 'lamsiekte' and 'styfsiekte' of South Africa, 'bog lameness' of Ireland, the 'creeps' and 'cripples' of Australia and the 'slikkesyken' of Norway are all now known to be the result of $P$ deficiency of the native pastures. These are nutritional diseases in the classical sense that they produce a well-recognized syndrome. There may too be even greater areas in which the highest levels of animal production are not attained owing to partial deficiency of $P$.

Bone abnormalities on pastures may not be solely the result of abnormalities of the $\mathrm{Ca}: \mathrm{P}$ ratio or of partial deficiencies of one or other element. Rickets in sheep when grazing young cereals has been recognized in both Australia and England (Ewer \& Bartrum, I948; Ewer, I950a). The disease is cured by single massive doses of Vitamin D. In Ewer's studies the vitamin D activity of the oats used was 80-1 20 i.u./100 g dry matter (Ewer, I950 b). These values are higher than the present postulated minimal vitamin D requirement of 45 i.u./ $100 \mathrm{~g}$ dry matter, and a rachitogenic principle has been postulated to be present in the herbage. Similarly, 'bent-leg' in Scotland, which Elliot \& Orr (1926) showed could be cured by feeding $\mathrm{Ca}$ and vitamin D, was shown by Auchinachie \& Fraser (1932) to be completely prevented by additional vitamin $\mathrm{D}$ even if the diet was very low in $\mathrm{Ca}$.

Copper. It is not possible in the space available to deal with all the minor-element deficiencies that occur in native pastures, or with the suspected deficiencies due to so-called mineral imbalances, such as excessive potassium content in relation to sodium content. The $\mathrm{Cu}$ content of herbage has been selected to show briefly the many difficulties involved in the interpretation of analytical results from herbage.

Table 4 summarizes some analytical data for pasture herbage. It will be noted that diseases that are cured by giving $\mathrm{Cu}$ to the affected animal occur on pastures which differ very widely in $\mathrm{Cu}$ content. Only in the areas of Australia where swayback is endemic does the $\mathrm{Cu}$ content of the herbage fall below the estimated minimal requirement. On many pastures in Britain these $\mathrm{Cu}$-deficiency diseases occur; animals show low levels of $\mathrm{Cu}$ in blood and liver; they respond dramatically to $\mathrm{Cu}$ therapy, and yet 
no differences in $\mathrm{Cu}$ content can be found between the herbage they graze and the herbage of fields on which the disease is unknown. Many reasons have been suggested for this paradox, interference with the normal $\mathrm{Cu}$ metabolism of the ruminant by traces of lead, zinc or molybdenum having attracted most attention. Despite considerable work, however, no explanation has yet been found.

\section{Table 4. Copper content of pastures in relation to the requirement}

\section{of sheep and cattle}

Estimated minimal requirement

Normal grazings, Great Britain*

Normal grazings, Australia $†$

Areas where diseases cured by administration of $\mathrm{Cu}$ occur:

Swayback areas, Australia

Swayback areas, Derbyshire $\$$

Swayback areas, Scotland $\|$

Peat scours area, New Zealand 9

Peat scours area, England**

Copper pine areas, Caithness $\dagger \dagger$

Falling disease areas, Australia $\ddagger$

Polder disease areas, Holland $\S$

$$
\begin{gathered}
\text { Cu (p.p.m. } \\
\text { of herbage) } \\
5 \\
7-24 \\
7-12 \\
\\
1-4 \\
12-27 \\
4.4-9 \\
3.6 \text { (mean) } \\
8-26 \\
5-21 \\
\text { Less than } 2 \\
5-11
\end{gathered}
$$

- Eden (1944).

$\dagger$ Bennetts \& Beck (1942).

$\ddagger$ Beck (194I $b$ ).

$\S$ Innes \& Shearer (1940).

II Stewart, Farmer \& Mitchell (1946).

\author{
Cunningham ( $\left.1945^{-6}\right)$. \\ *** Allcroft (1946). \\ †† Jamieson \& Allcroft (1950). \\ I† Beck (I94I $a$ ). \\ $\S \S$ Brouwer, Frens, Reitsma \& Kalisvaart (1938).
}

Fat-soluble vitamins. Vitamin D supply from pasture has already been mentioned. The grazing animal of course receives most of its protection against rickets from sunlight. In herbage crops it appears that it is largely the small dead areas of the leaf which contain vitamin $D$, presumably as a result of irradiation. From the scanty analyses available the vitamin $\mathrm{D}$ content of the pasture plants does, however, appear to be highly variable.

The enormous quantities of $\beta$-carotene present in grass are nearly always sufficient to meet requirements. Early young grass contains 300-400 times as much carotene as the animal requires, and, though the carotene content falls rapidly with advance of season, it remains above requirement. Field deficiencies do occur, however, where animals are maintained on very poor, mature, dry, bleached ranges or where such fodder is supplemented with cereals and oilcakes with very low vitamin A activity (Hart \& Guilbert, 1933). Drought markedly reduces the vitamin A activity of pasture, and under such conditions vitamin A deficiency will occur (Gunn, 1942). The weather in this country precludes such deficiencies on natural pastures.

The vitamin E content of pasture grasses is quite high, but nevertheless deficiency syndromes in young lambs and young calves have been recorded. These respond to vitamin E therapy (Willman, Asdell, Grams \& Hagan, 193I; Willman, Loosli, Asdell, Morrison \& Olafson, 1945, 1946; Stamp \& Blaxter, 195 I; Vawter \& Records, 1947). Analyses of food in such instances have not yet shown major deficiencies of tocopherols in the diet. 
Water-soluble vitamins. Table 5 makes a comparison of requirements of animals for components of the vitamin B complex with the composition of pasture herbage in respect of these nutrients. In general, grass can be regarded as an excellent source of riboflavin, nicotinic acid, pantothenic acid, pyridoxin and biotin (the last two are not

Table 5. Content of vitamins of the $B$ complex in grasses in relation to the generalized minimal requirements of herbivora for these vitamins

(All values expressed in $\mathrm{mg} / 100 \mathrm{~g}$ dry material)

\begin{tabular}{|c|c|c|c|c|}
\hline & Aneurin & Riboflavin & $\begin{array}{l}\text { Nicotinic } \\
\text { acid }\end{array}$ & $\begin{array}{l}\text { Pantothenic } \\
\text { acid }\end{array}$ \\
\hline Requirement & 0.1 & 0.15 & $1 \cdot 0$ & 0.5 \\
\hline \multicolumn{5}{|l|}{ Content in: } \\
\hline Young cereals* & $0 \cdot 2-1 \cdot 3$ & $1 \cdot 5-2 \cdot 6$ & $5 \cdot 3-9 \cdot 3$ & $I \cdot 4-r \cdot 8$ \\
\hline Mixed grassland herbage $\uparrow$ & $0.2 \pm 0.01$ & $0.9 \pm 0.04$ & $3.0 \pm 0.2$ & $0.9 \pm 0.04$ \\
\hline Lucerne including dehydrated crop & $0.26 * *$ & $\begin{array}{c}0.9-2.6 \pm \$ \\
0.9-2.6 * * \\
1.67\end{array}$ & $\begin{array}{c}6 \cdot 6-15 \cdot 7 \| \\
4 \cdot 6 *\end{array}$ & $\begin{array}{r}3.3-4.65 \\
2.50 * *\end{array}$ \\
\hline $\begin{array}{l}\text { Poor 'grasses' (crested dog's-tail, flying } \\
\text { bent draw moss) } \dagger\end{array}$ & $0.2-0.4$ & $I \cdot 2-2 \cdot 0$ & $4 \cdot 4-4 \cdot 6$ & $0.5-1 \cdot 7$ \\
\hline Conclusion & $\begin{array}{l}\text { Lowest } \\
\text { margin of } \\
\text { safety }\end{array}$ & $\begin{array}{c}\text { Highly } \\
\text { adequate }\end{array}$ & $\begin{array}{l}\text { Highly } \\
\text { adequate }\end{array}$ & Adequate \\
\hline \multicolumn{5}{|c|}{$\begin{array}{l}\text { Kohler (1944). } \\
\text { Thomas \& Walker (1949); in the first instance mean values with their standard errors. } \\
\text { I Hanke \& Perkins (1942). } \\
\$ \text { Hunt \& Bethke (1940). } \\
\text { II Hale, Davis \& Baldwin (1942). }\end{array}$} \\
\hline
\end{tabular}

shown in the table). Grass does, however, tend to be low in aneurin. As far as ruminant animals are concerned this may be of some importance, since the evidence for the synthesis of adequate amounts of this vitamin is by no means unimpeachable (Kon \& Porter, I947-8). There is evidence too (Wegner, Booth, Elvehjem \& Hart, I940) that the level of vitamin $B_{1}$ has a decided influence on the rate of synthesis in the rumen of other members of the $B$ complex. In this respect a disease of young cattle characterized by ataxia and abnormalities of heart action has been shown to respond to vitamin $B_{1}$ therapy in Norway (Dynna \& Thune, 1941). How far the 'stravelsjuka' of cattle in Sweden is partly the result of a secondary vitamin B-complex deficiency is not known (Hoflund \& Hedström, 1949). Vitamin C has not been included in this study, since it is probably not required in the diet of domesticated animals. The content in fresh young grass is extremely high (Booth, r 942 ).

Toxic substances. The conversion of pastures to human food is limited not only by nutrient deficiencies of the forage. Limitations arise from the presence of toxic minerals taken up by plants from the soil and from toxic organic compounds synthesized by plants growing in the pastures. Some of the toxic minerals may be regarded as surface contaminants of the herbage, arising from soil dust or industrial fumes. Lead (Allcroft \& Blaxter, 1950), fluorine (Boddie, 1945, 1947) and arsenic (Sommer, Schwarzendahl \& Bergmann, 1944; Grumbach, 1944) all come in this category. Selenium poisoning which causes blind staggers in cattle in Dakota and Wyoming (Moxon \& Rhian, 1943) is, however, the result of uptake of selenium by the plants themselves. In these seleniferous areas no solution to the problem has been 
found and hundreds of thousands of acres have been virtually abandoned by beast and man. Molybdenum poisoning, which causes the 'teart', or scouring disease, of cattle in this country, is similarly due to uptake of molybdenum from the soil (Lewis \& Watson, 1942). It can be cured by administration of copper (Ferguson, Lewis \& Watson, 1943), and the disease is no longer a serious problem in the areas concerned. Accumulation of nitrates in herbage, more particularly oat hay and rape, results in toxic syndromes in cattle as the result of methaemoglobin formation (Bradley, Eppson \& Beath, 1940).

The number of plants poisonous to livestock is legion. In this country deaths occur every year as the result of the ingestion of bracken, ragwort, water dropwort, horsetails, hemlock and other plants. In other countries single species may cause wholesale outbreaks of poisoning. This is true of the 'geeldikkop' of the Karroo which is due to photosensitization by Tribulus and other plants (Quin, 1948) and of similar photosensitizing diseases which occur when species of Hypericum are ingested (Dodd, I920; Seddon \& Belschner, 1927-8). In Australia the presence of oestrogens in subterranean clover is sufficient to cause abortion in ewes and sexual abnormalities in castrated male sheep (Bennetts, 1947). In this country similar oestrogens have been found in pasture herbage (Bartlett, Folley, Rowland, Curnow \& Simpson, 1948) and one case of comparable defects in sheep has been observed (Stamp, I95I).

\section{Conclusions}

The full conversion of the herbage of many grazings to food for man is limited. Limitations in the utilization of the proteins, fats and carbohydrates of the herbage arise primarily from mineral deficiencies of soil and pasture; to a very minor extent from vitamin deficiencies of the herbage and to an unknown extent from the presence of toxic elements and organic compounds in the herbage. Deficient pastures may support livestock at low levels of productivity; the removal or neutralization of those limiting factors at present known could, however, result in great increases in the total production of human food.

\section{REFERENCES}

Allcroft, R. (1946). Nature, Lond., 158, 796.

Allcroft, R. \& Blaxter, K. L. (1950). F. comp. Path. 60, 209.

Arnold, A. \& Elvehjem, C. A. (1938). F. Nutrit. 15, 403 .

Auchinachie, D. W. \& Fraser, A. H. H. (1932). F. agric. Sci. 22, 560.

Bartlett, S., Folley, S. J., Rowland, S. J., Curnow, D. H. \& Simpson, S. A. (1948). Nature, Lond., I62, 845 .

Bauernfeind, J. C., Norris, L. C. \& Heuser, G. F. (1942). Poult. Sci. 21, I36.

Beck, A. B. (1941 a). F. Dep. Agric. W. Aust. 17, 4 I.

Beck, A. B. (194I b). F. Dep. Agric. W. Aust. 18, 285.

Bennetts, H. W. (1947). Aust. vet. F. 23, 10.

Bennetts, H. W. \& Beck, A. B. (1942). Bull. Coun. sci. industr. Res. Aust. no. 147.

Boddie, G. F. (1945). Proc. Nutr. Soc. 3, 94.

Boddie, G. F. (1947). Vet. Rec. 59, 301.

Booth, V. (1942). Chem. छ' Ind. 6I, 255.

Bradley, W. B., Eppson, H. F. \& Beath, O. A. (1940). Bull. Wyo. agric. Exp. Sta. no. 24I.

Brouwer, F., Frens, A. M., Reitsma, P. \& Kalisvaart, C. (1938). Landbouwk. Onderz. Rijkslandbouwproefstation, Hoorn, no. 44 (4) C, p. 267.

Cowgill, G. R. \& Palmieri, M. L. (1933). Amer. 7. Physiol. 105, 146.

Cunningham, I. J. (1945-6). N.Z. F. Sci. Tech. 27, sect. A, p. 38 r.

Dodd, S. (1920). F. comp. Path. 33, 105. 
Dynna, O. \& Thune, I. (1941). Norsk VetTidsskr. 53, 94.

Eden, A. (1944). Э. comp. Path. 54, 220.

Elliot, W. \& Orr, J. B. (1926). F. agric. Sci. 16, 25.

Ewer, T. K. (1950a). Vet. Rec. 62, 603.

Ewer, T. K. (1950b). Nature, Lond., 166, 732.

Ewer, T. K. \& Bartrum, P. (1948). Aust. vet. F. 24, 73.

Fagan, T. W. (1931). Agric. Progr. 8, 65.

Ferguson, W. S., Lewis, A. H. \& Watson, S. J. (1943). F. agric. Sci. 33, 44.

Grumbach, H. (1944). Z. Tierernähr. Futtermittelk. 8, 255.

Guilbert, H. R., Howell, C. E. \& Hart, G. H. (1940). F. Nutrit. 19, 91.

Guilbert, H. R. \& Loosli, J. K. (1949). Proc. int. Congr. Zootech. v. Paris, p. I67.

Guilbert, H. R. \& Loosli, J. K. (195I). F. Anim. Sci. Io, 22.

Gunn, R. M. C. (1942). Aust. vet. F. 18, 94.

Gutowska, M. S. \& Parkhurst, R. T. (1942). Poult. Sci. 21, 277.

Hale, E. B., Davis, G. K. \& Baldwin, H. R. (1942). F. biol. Chem. 146, 553.

Hanke, A. R. \& Perkins, A. T. (1942). Poult. Sci. 21, 195.

Hart, G. H. \& Guilbert, H. R. (1933). Bull. Calif. agric. Exp. Sta. no. 560.

Henderson, H. O. \& Weakley, C. E. Jr. (1930). Bull. W. Va. agric. Exp. Sta. no. 23 r.

Hoflund, S. \& Hedström, H. (1949). Acta agric. Suecana, 3, 121.

Holmes, W. (1949). F. agric. Sci. 39, 128.

Hunt, C. H. \& Bethke, R. M. (1940). F. Nutrit. 20, 175.

Innes, J. R. M. \& Shearer, G. D. (1940). F. comp. Path. 53, 1.

Jamieson, S. \& Allcroft, R. (1950). Brit. $\mathscr{F}$. Nutrit. 4, I6.

Kohler, G. O. (1944). F. biol. Chem. 152, 215.

Kon, S. K. \& Porter, J. W. G. (1947-8). Nutr. Abstr. Rev. r7, 31.

Lardinois, C. C., Elvehjem, C. A. \& Hart, E. B. (1944). F. Dairy Sci. 27, 875.

Lewis, A. H. \& Watson, S. J. (1942). F. Minist. Agric. 49, 82.

Lyons, M. (1939). Bull. Ark. agric. Exp. Sta. no. 374.

Mitchell, H. H. (1947). F. Anim. Sci. 6, 365.

Mitchell, H. H. (1950). Nutrient Requirements as Related to Body Size and Body Function, p. 165. Scientia Series 6, 44th year. Milano.

Mitchell, H. H. \& McClure, F. J. (1937). Bull. nat. Res. Coun., Wash., no. 99.

Moore, L. A., Thomas, J. W., Jacobsen, W. C., Melin, C. G. \& Shepherd, J. B. (1948). Y. Dairy Sci. 3I, 489.

Moxon, A. L. \& Rhian, M. (1943). Physiol. Rev. 23, 305.

Orr, J. B. (1929). Minerals in Pastures. London: H. K. Lewis and Co. Ltd.

Percival, E. G. V. (I952). Brit. F. Nutrit. 6, 104.

Quin, J. I. (1948). Fmg S. Afr. 23, 677.

Reed, O. E. \& Huffman, C. F. (1930). Bull. Mich. agric. Exp. Sta. no. 105.

Roloff, F. (1866). Virchows Arch. 37, 433.

Russell, F. C. (1944). Tech. Commun. Bur. Anim. Nutrit., Aberd., no. I5.

Schneider, B. H. (1947). Feeds of the World, their Digestibility and Composition. University of West Virginia Agricultural Experiment Station.

Seddon, H. R. \& Belschner, H. G. (1927-8). Vet. Res. Rep. N.S.W. no. 5, p. 103.

Sheehy, E. J., O'Donovan, J., Day, W. R. \& Curran, S. (1948). F. Dep. Agric., Eire, 45, 5.

Sommer, O., Schwarzendahl, A. \& Bergmann, H. (1944). Z. Tierernähr. Futtermittelk. 8, 269.

Stamp, J. T. (195I). Private communication.

Stamp, J. T. \& Blaxter, K. L. (I95I). Unpublished observations.

Stewart, J., Farmer, V. C. \& Mitchell, R. L. (1946). Nature, Lond., I57, 442.

Synge, R. L. M. (1952). Brit. F. Nutrit. 6, 100.

Theiler, A., Green, H. H. \& Viljoen, P. R. (1915). Rep. vet. Res. S. Afr. 3 and 4, 1.

Thomas, B., Escritt, J. R. \& Trinder, N. (1945). Emp. F. exp. Agric. 13, 93.

Thomas, B. \& Thompson, A. (1948). Emp. F. exp. Agric. 16, 221.

Thomas, B. \& Trinder, N. (1947). Emp. F. exp. Agric. 15, 237.

Thomas, B. \& Walker, H. F. (1949). Emp. F. exp. Agric. 17, 170.

Thomas, J. W. \& Moore, L. A. (1948). F. Dairy Sci. 31, 689.

Van Etten, C., Ellis, N. R. \& Madsen, L. L. (1940). F. Nutrit. 20, 607.

Vawter, L. R. \& Records, E. (1947). F. Amer. vet. med. Ass. I10, 152.

Watson, S. J. (1939). The Science and Practice of Conservation: Grass and Forage Crops. London: Fertilizer and Feedingstuffs Journal.

Wegner, M. I., Booth, A. N., Elvehjem, C. A. \& Hart, E. B. (1940). Proc. Soc. exp. Biol., N. Y., 45, 769. Willman, J. P., Asdell, S. A., Grams, W. T. \& Hagan, W. A. (193 I). Proc. Amer. Soc. Anim. Prod. p. 23 I. Willman, J. P., Loosli, J. K., Asdell, S. A., Morrison, F. B. \& Olafson, P. (1945). F. Anim. Sci. 4, 128. Willman, J. P., Loosli, J. K., Asdell, S. A., Morrison, F. B. \& Olafson, P. (1946). Cornell Vet. 36, 200. 